\title{
Market structure and price controller of beef cattle in North Sulawesi
}

\author{
Erwin Wantasen ${ }^{1, *}$, Sintya Umboh $^{1}$, and Jein Rini Leke ${ }^{2}$ \\ ${ }^{1}$ Department of Socio-Economic, Faculty of Animal Husbandry, Sam Ratulangi University, \\ Jalan Kampus Manado, 95115-Indonesia \\ ${ }^{2}$ Department of Animal Production, Faculty of Animal Husbandry, Sam Ratulangi University, \\ Jalan Kampus Manado, 95115-Indonesia
}

\begin{abstract}
The purpose of this study is to analyze the market structure and controller of beef cattle prices in North Sulawesi. The location of the research was purposively determined, namely Manado City, Tomohon City, and Regency of Minahasa as the trade center of beef cattle in North Sulawesi. Furthermore, respondents were determined by the snowball sampling, started by obtaining information about breeders of beef cattle as business consumers and, also, the end consumers through the Department of Agriculture and Animal Husbandry in the three research areas. Through the snowball technique, 120 respondents consisted of 10 endconsumers/business consumers of beef cattle, 10 intermediate traders, and 100 breeders of beef cattle. The data, then, were analyzed using the concentration ratio model and Hirscman-Herfindahl Index to measure the market structure and asymmetric price transmission analysis to detect the controllers of beef cattle prices. The result shows that the structure of the beef cattle market in North Sulawesi led to an oligopoly with the highest concentration; while, the controllers of beef cattle prices were the endconsumer as business consumers of live beef cattle.
\end{abstract}

\section{Introduction}

Based on the data of [1], the total of beef cattle in North Sulawesi was 135,292 cattle or $0.95 \%$ of the total population of beef cattle in Indonesia. Data obtained from [1] demonstrates that $42 \%(260,861$ households of 621,098 households in North Sulawesi raised beef cattle as a commodity supporting household income.

In North Sulawesi, the sub-sector of beef cattle contributes to household income, regional income, job procurement ad export profit $[2,3,4]$. As beef cattle has a significant role in the level of household, it effects on the socio-economic life, such as solving household's economic issues, assets enhancer of household's wealth and value depositor when the market and formal financial institution are unavailable [5,6,7].

Though the total of breeders of beef cattle in North Sulawesi is sufficiently great in amount, the contribution of beef cattle toward household income is still low $[8,9,10]$. It is due to the shortage of market orientation on beef cattle in North Sulawesi, indicated by

\footnotetext{
* Corresponding author: erwinwantasen@yahoo.co.id
} 
existing market hindrances, such as lower bargaining power of breeders of beef cattle in the downstream or marketing sector so that cattle's market involving small-scale breeders has not been efficient, subsequently followed by a relatively lower profit share and higher share of marketing cost by breeders. Other market impediments dealt with by breeders are limitation of market information-particularly on price, insufficient marketing infrastructures, the non-optimized performance of marketing institutions, minor legal assurance and marketing regulation, and limited access to financial services for breeders [11-15].

Currently, the research regarding beef and cattle marketing still focuses on one marketing region and reviews on the characterization of beef cattle's chain supply, consumer's preference on beef cattle's products, price and offering, marketing margin of cattle, marketing efficiency, beef cattle's demand, marketing strategy, and product upgrading and profitability of cattle [16-19]. The marketing of beef cattle in North Sulawesi has involved more than one marketing region, forming a marketing chain from upstream to downstream, and linkage between existing marketing institutions in such region. The linkage of marketing institutions will create a certain market structure that can be measured by the ratio of market concentration $[20,21]$. Such issue has not been reviewed in previous researches in North Sulawesi, mainly marketing of beef cattle. Therefore, the research aims to analyze the market structure and price controller of beef cattle in North Sulawesi involving breeders of beef cattle, intermediate trader and end-consumer of cattle, acting as a business consumer of beef and owner of abattoirs and user of the slaughterhouse. The endconsumer of live cattle is a retailer, working in a traditional market, and distributor of beef cattle in a supermarket.

\section{Research method}

\subsection{Site and time}

The research was performed on February-March 2021 in Manado City, Tomohon City, and Regency of Minahasa as the trading center of beef cattle in North Sulawesi. Based on the characteristics of each region, Manado City has slaughterhouse and abattoirs, endconsumers and business consumers of beef cattle, hotels, restaurants, modern and traditional market, hospitals and universities. Next, Tomohon City has abattoirs, endconsumers as business consumers, breeders, group of cattle breeders, traditional and modern market offering daily beef products, and education center; while Regency of Minahasa has the only one center of livestock broker market in Province of North Sulawesi, located in District of Kawangkoan. There were breeders and group of cattle breeders becoming the input of beef cattle for Manado and Tomohon City. A total amount of 42.278 cattle $(31.25 \%)$ of 135,292 beef cattle in North Sulawesi were located in three research sites, and the rest dispersed in 12 Regencies and other existing cities in North Sulawesi.

\subsection{Sampling method, type of data, and data collecting technique}

The sampling method of respondents was done by Snowball (22), initially obtaining information of the existence of business consumer of beef cattle (end-consumer of live beef cattle), who was also the owner of abattoirs and slaughterhouse, and both retailer to traditional market and distributor of beef to supermarket through various related institutions existing in Manado City, Tomohon City, and Regency of Minahasa. Additionally, the 
information of end-consumer of beef cattle obtained by snowball showed the existence of intermediate traders and breeders of beef cattle, as seen in Table 1.

Table 1. Samples of study

\begin{tabular}{|l|r|r|r|r|}
\hline $\begin{array}{c}\text { Location of the } \\
\text { beef cattle } \\
\text { market }\end{array}$ & $\begin{array}{c}\text { Breeders of } \\
\text { beef cattle } \\
\text { (people) }\end{array}$ & $\begin{array}{c}\text { Intermediate } \\
\text { traders (people) }\end{array}$ & $\begin{array}{c}\text { End-consumer of } \\
\text { beef cattle } \\
\text { (people) }\end{array}$ & $\begin{array}{c}\text { Total of } \\
\text { samples } \\
\text { (people) }\end{array}$ \\
\hline Manado City & 18 & 3 & 7 & 28 \\
\hline Tomohon City & 28 & 2 & 3 & 33 \\
\hline $\begin{array}{l}\text { Regency of } \\
\text { Minahasa }\end{array}$ & 54 & 5 & 0 & 59 \\
\hline Total & 100 & 10 & 10 & 120 \\
\hline
\end{tabular}

Data of the research consisted of primary and secondary data gained by survey using a questionnaire. The primary data was obtained from a sample of breeders as respondents, such as beef cattle price, marketing cost, a total of beef cattle selling, a total of purchased beef cattle, an income of each marketing institution. In addition, the secondary data was derived from government agencies related to this research and scientific journals published online on the internet.

\subsection{Data analysis}

\subsubsection{Analysis of the market structure}

The theory of industrial economy and market structure can be detected by both concentration and barriers to entry [23]. While in this research, the detection of the market structure was conducted by analyzing market concentration. The concentration was done by measuring the size of company distribution in the industry. To measure it, there were two (2) ways, such as: a) Ratio concentration (Rc) by the following equation [24,25].

$$
\mathrm{Rc}=\frac{\text { Purchased volume }}{\text { Marketed volume }} \mathrm{X} 100 \%
$$

If the level of ratio concentration is between 0-40 percent, the market structure is perfect competition and leads to an oligopoly system with a lower level of concentration. Whereas the level of ratio concentration is $40-70$ percent, the market structure is an oligopoly with a medium level of concentration. The level of ratio concentration, in addition, is 70-100 percent, the market structure of beef cattle is an oligopoly with a higher level of concentration, directing to monopoly market. While b), in Herfindahl index (HI), the analysis is to measure market strength [26]. HI is a sum of the market share square of all companies in the industry, by the following equation:

$$
\mathrm{HI}=\mathrm{S} 1^{2}+\mathrm{S} 2^{2}+\ldots \ldots . . . \mathrm{Sn}^{2}
$$

$\mathrm{S}$ is the market share of each company in the industry

According to the U.S. Department of Justice and the Federal Trade Commission, the amount of $\mathrm{HI}$ is divided into several criteria. First, $\mathrm{HI}<0.01$ means market approaching perfect competition; second, $\mathrm{HI}<0.1$ is a non-concentrated market; third, $0.1<\mathrm{HI}<0.18$ is a medium-concentrated market, and, the last, $\mathrm{HI}>0.18$ means a higher concentrated market. 


\subsubsection{Analysis of price controller}

Analysis model employed in this research was asymmetric price transmission since it considered dimension of inter-period price changes [27, 28]:

$$
\delta \mathrm{H}_{\mathrm{rt}}=\beta_{0+} \beta_{1} \delta \mathrm{H}_{\mathrm{ft}}^{+}+\beta 2 \delta \mathrm{H}_{\mathrm{ft}}{ }^{-}+\varepsilon_{\mathrm{t}}
$$

Where, $\delta \mathrm{Hrt}=$ First derivation of price in downstream

$\delta \mathrm{H}_{\mathrm{ft}}{ }^{+}=$Movement of increasing price in upstream

$\delta \mathrm{H}_{\mathrm{ft}}{ }^{-}=$Movement of decreasing price in upstream

The above model implicitly explains that price movements at the upstream level are a driver of price changes at retail level or we can say that the price of upstream level is the granger cause of the price at the downstream level. The above equation requires a granger causality test to know price movement upstream as controller or price drivers on downstream. The application of such an equation finds obstacles due to any difficulty in obtaining data of time series in respondents so that it only gains data of cross-section in one time. Thus, the research only applies Granger casuality tests on data of cross-section [29].The result of the Granger casuality test is used to detect the most dominant transaction impact in the price controller of the beef cattle market [30]. In addition, the causality test is applied to data of cross-section, obtained by comparing the value of $\mathrm{F}$ test from the following three equations [31]:

$\mathrm{P}_{\mathrm{pb}}=\mathrm{f}\left(\mathrm{P}_{\mathrm{pt}}, \mathrm{P}_{\mathrm{kb}}\right) ; \mathrm{F}_{1}$, price domination in the level of breeders' beef cattle

$\mathrm{P}_{\mathrm{pt}}=\mathrm{f}\left(\mathrm{P}_{\mathrm{pb}}, \mathrm{P}_{\mathrm{kb}}\right) ; \mathrm{F}_{2}$, price domination in the level of intermediate traders

$\mathrm{P}_{\mathrm{kb}}=\mathrm{f}\left(\mathrm{P}_{\mathrm{pb}}, \mathrm{P}_{\mathrm{pt}}\right) ; \mathrm{F}_{3}$, price domination in the level of end-consumer/business consumer/owner of abattoirs (TPA)/user of the slaughterhouse $(\mathrm{RPH}) /$ retailer of beef

Where $\mathrm{P}_{\mathrm{pb}}$ is a price in the level of breeders, $\mathrm{P}_{\mathrm{pt}}$ is a price in the level of intermediate traders and $\mathrm{P}_{\mathrm{kb}}$ is a price in the level of end-consumer of beef cattle as business consumer/owner of abattoirs (TPH) and user of the slaughterhouse (RTH). The equation of the biggest $\mathrm{F}$ statistic value shows the leading price domination in the level of subproducer.

\section{Result and discussion}

\subsection{Characteristics of respondent}

This research involved 120 respondents, where the majority of lower education background consisted of graduated of Junior High School (35.83\%) and elementary school (30.65\%), as seen in Table 2 below.

Based on the above table, it means that ability in analyzing market opportunity and reasoning to the agribusiness of beef cattle required government's contribution, including university. According to the age of respondents, $32.50 \%$ of breeders were by the age range of 41-50 years of old, and 25.83\% were51-60 years of old. The above data describes that the age of respondents involved in the marketing of beef cattle in North Sulawesi was productive. Next, about $60 \%$ of respondents had experienced more than 10 years in the marketing of beef cattle. Such experience, indeed, had benefited breeders/traders and/or end-consumer of beef cattle since livestock was savings that could be sold any time for the family's needs. Selling of beef cattle by breeders was only performed as breeders required daily cost so that breeders' income was dominated by foods crop. While, beef cattle marketed in the research's site was Ongole breed (PO), having a clean-white color of skin, 
firm and giant type of body, and special mark in hump or back of the head, indicating suitable for hard work and well-preferred by consumer and traders of beef cattle. The result of this research finds out that the weight of beef cattle owned by breeders was between 300 kg.-350 kg. Nonetheless, the selling price of beef cattle in the research's site heavily depended on the physical appearance of cattle and was not based on beef cattle's weight estimation. In the market, the selling price of beef cattle was around 6 up to 20 million Rupiah per cattle depending on age and physical shape. The characteristic of breeder's and trader's income of beef cattle in North Sulawesi shows that the rate of income was IDR 2,500,000-IDR 10,000,000/month. Therefore, breeders and traders sufficiently relied on beef cattle as one of the main household livings, even though it had not become the only living source of breeder's household [6,7,9]. It happened since some of the breeders still counted on foods plant as the main source of living.

Table 2. Characteristics of respondent

\begin{tabular}{|c|c|c|c|c|c|c|c|c|}
\hline \multirow[b]{2}{*}{ Characteristics } & \multicolumn{2}{|c|}{ Manado } & \multicolumn{2}{|c|}{ Tomohon } & \multicolumn{2}{|c|}{ Minahasa } & \multicolumn{2}{|c|}{ Total } \\
\hline & $\begin{array}{c}\text { Total } \\
\text { (people) }\end{array}$ & $\%$ & $\begin{array}{c}\text { Total } \\
\text { (people) }\end{array}$ & $\%$ & $\begin{array}{c}\text { Total } \\
\text { (people) }\end{array}$ & $\%$ & $\begin{array}{c}\text { Total } \\
\text { (people) }\end{array}$ & $\%$ \\
\hline \multicolumn{9}{|c|}{ Education } \\
\hline Elementary & 9 & 31.57 & 9 & 28.55 & 20 & 34.00 & 38 & 31.65 \\
\hline $\begin{array}{l}\text { Junior High } \\
\text { School }\end{array}$ & 11 & 38.48 & 12 & 35.70 & 20 & 34.00 & 43 & 35.83 \\
\hline $\begin{array}{l}\text { Senior High } \\
\text { School }\end{array}$ & 8 & 27.32 & 11 & 31.85 & 17 & 28.50 & 36 & 30.00 \\
\hline Bachelor & 1 & 2.64 & 1 & 3.90 & 2 & 3.5 & 3 & 2.70 \\
\hline Total & 28 & 100.00 & 33 & 100.00 & 59 & 100.00 & 120 & 100.00 \\
\hline \multicolumn{9}{|c|}{ Age (Years old) } \\
\hline$<30$ & 1 & 2.63 & 1 & 2.38 & 1 & 2.25 & 3 & 2.50 \\
\hline $31-40$ & 7 & 23.68 & 8 & 23.81 & 15 & 25.42 & 30 & 25.00 \\
\hline $41-50$ & 9 & 34.21 & 11 & 33.33 & 19 & 32.50 & 39 & 32.50 \\
\hline $51-60$ & 7 & 26.32 & 9 & 28.57 & 15 & 25.42 & 31 & 25.83 \\
\hline$>60$ & 4 & 13.16 & 4 & 11.91 & 9 & 14.91 & 17 & 14.16 \\
\hline Total & 28 & 100.00 & 33 & 100.00 & 59 & 100.00 & 120 & 100.00 \\
\hline \multicolumn{9}{|c|}{ Experience (Years) } \\
\hline $1-5$ & 5 & 18.24 & 7 & 21.34 & 11 & 19.50 & 23 & 19.16 \\
\hline $6-10$ & 4 & 15.97 & 5 & 16.76 & 5 & 18.00 & 14 & 11.67 \\
\hline $11-20$ & 6 & 34.12 & 12 & 35.17 & 19 & 32.40 & 37 & 30.83 \\
\hline$>20$ & 9 & 31.67 & 9 & 26.73 & 18 & 30.10 & 36 & 30.00 \\
\hline Total & 28 & 100.00 & 33 & 100.00 & 59 & 100.00 & 120 & 100.00 \\
\hline \multicolumn{9}{|c|}{ Household's income (IDR/month) } \\
\hline$<1,000,000-$ & 1 & 2.69 & 1 & 2.37 & 3 & 4.95 & 5 & 4.16 \\
\hline $\begin{array}{l}1,000,000- \\
2,000,000\end{array}$ & 3 & 10.35 & 4 & 11.92 & 9 & 14.96 & 16 & 13.33 \\
\hline $\begin{array}{l}>2,000,000- \\
5,000,000\end{array}$ & 12 & 44.47 & 16 & 47.61 & 25 & 42.56 & 53 & 44.17 \\
\hline $\begin{array}{l}>5,000,000- \\
10,000,000\end{array}$ & 10 & 34.24 & 10 & 30.96 & 18 & 30.00 & 38 & 31,66 \\
\hline$>10,000,000$ & 2 & 8.25 & 2 & 7.15 & 4 & 7.44 & 8 & 6.67 \\
\hline Total & 28 & 100.00 & 33 & 100,00 & 59 & 100,00 & 120 & 100,00 \\
\hline
\end{tabular}

The characteristic of breeders and traders of beef cattle as the respondent in North Sulawesi was in line with some previous researches $[32,33,34]$, reporting that the rate of breeders' age was in the productive age, but their education was relatively low in developing country so that it required counseling of counselor in business planning and cattle marketing. Further, beef cattle were a side job where breeders' income had not been 
maximally obtained; though, there was a higher selling price. It was because beef cattle were still utilized as labor in foods plant and estate, and they would be sold if breeders had urgent cash or difficulty in seeking forages $[35,36]$.

\subsection{Market structure}

The analysis result of ratio concentration of beef cattle marketing in three research sites is presented in Table 3, displaying that the cumulative percentage of ratio concentration (Rc) of three beef cattle markets was 75.63 percent. It, then, indicates that market structure tend to an oligopoly with a higher concentration or fierce oligopoly. If partially seen, the market located in Manado City and regency of Minahasa had an oligopoly with a higher concentration, while Tomohon City had a medium concentration of oligopoly.

Table 3. Value of ratio concentration (Rc) of beef cattle marketing in North Sulawesi

\begin{tabular}{|l|r|r|r|}
\hline \multicolumn{1}{|c|}{ Market's site } & $\begin{array}{c}\text { Rate of purchased } \\
\text { volume } \mathbf{( K g )}\end{array}$ & $\begin{array}{c}\text { Rate of sold } \\
\text { volume (kg) }\end{array}$ & $\begin{array}{c}\text { Ratio concentration } \\
\text { (Rc) (\%) }\end{array}$ \\
\hline Manado City & 301 & 355 & 84.78 \\
\hline Tomohon City & 240 & 348 & 68.96 \\
\hline Regency of Minahasa & 311 & 425 & 73.17 \\
\hline Total & & & 75.63 \\
\hline
\end{tabular}

Under the level of medium concentration, new actors of beef cattle were enabled to enter, though they had difficulty in competing with older actors. Contrastingly, the market structure having a higher concentration of oligopoly was highly tough entered by new marketers [37]. This result of the research was following previous research [24,38], arguing that the market concentration of beef cattle was classified as a higher concentration of oligopoly, so that it tends inefficient. In contrast, the result of this research was different from other previous researches, stating that the concentration level of the beef cattle market changed based on time, but the level was in low to a medium concentration where the oligopoly still enabled the entry of new actors in beef cattle market $[39,26]$.

In addition, the calculation of Herfindahl Index (HI) value was 0.2102, meaning that there was a higher concentration of beef cattle market in North Sulawesi. This postulates that the existence of market strength concentration in some traders/sellers of beef cattle, so that it influenced other traders/sellers, mainly in pricing or quality of beef cattle. Selling value and quality of beef cattle in North Sulawesi incliningly were determined by traders and not breeders since traders valued livestock due to their physical appearance and not weight. This finding was consistent with research conducted by [40]. It was because the market of beef cattle in North Sulawesi was dominated by a broker and big trader as a business consumer, owner of abattoirs (TPH) and the slaughterhouse (RPH), and retailer of beef cattle in both traditional and modern market.

\subsection{Analysis of price controller of beef cattle}

The distribution line of beef cattle marketing in the research's site was, initially, from a breeder-intermediate trader/broker/inter-city/regency trader within a province and/or inter-province-big trader as end-consumer/business consumer of beef cattle as the owner of abattoirs and user of the slaughterhouse/retailer of beef cattle to a traditional and modern market. In North Sulawesi, the price of beef cattle itself was not based on weight but physical appearance, which a firm body and white skin having some special characteristics would have a higher price by a trader. Purchasing price in the level of breeders was around IDR 6,000,000- IDR. 10,000,000 per head and its selling price by a 
trader or big trader as end-consumer of beef cattle were in the range of IDR 15,000,000IDR 20,000,000 per head. In the market, there was a fierce concentration of market strength for a big trader of beef cattle as both business consumers and retailers of beef cattle. As a result, the trader could interfere with other traders, mainly in either pricing or supply quality of beef cattle. This can be seen from the analysis result of price movement in asymmetric price transmission (APT). The result depicts that driver of price movement was transactional price between end-consumer of beef cattle as a business consumer and user of the slaughterhouse and retailer of beef cattle with intermediate trader/broker. In other words, the price established from a transaction of the big trader as end-consumer of beef cattle and business consumer/user of the slaughterhouse and retailer of beef cattle with intermediate trader/broker would be followed by the following distribution channel. Thus, this research was synergized with previous research arguing that the price of beef cattle was significantly determined by several factors, such as market structure, the physical condition of beef cattle, type of beef cattle, culture, and access to transportation $[41,42]$.

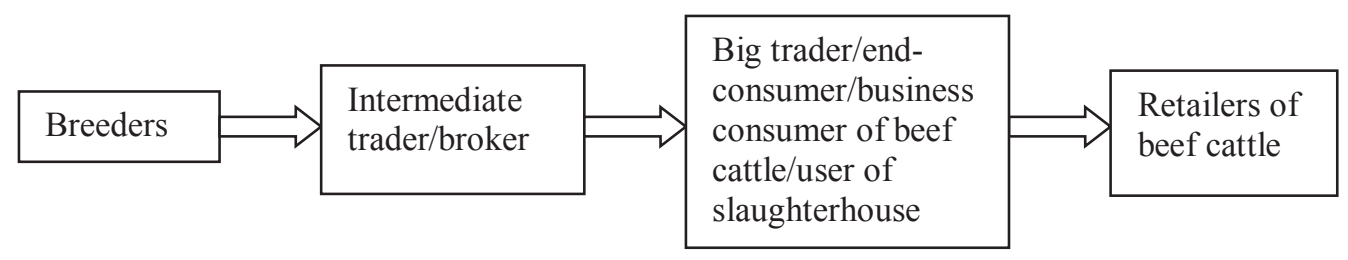

$$
\begin{array}{lll}
\mathrm{F} 1=0.207 & \mathrm{~F} 2=3.928 & \mathrm{~F} 3=1.005 \\
p=0.835 & p=0.026 & p=0.859
\end{array}
$$

Fig. 1. Analysis of pricing in marketing line of beef cattle in North Sulawesi

Figure 1 above shows that the biggest value of $F$ statistic was 3.928 arising in the transaction between intermediate traders/brokers with the big traders as endconsumers/business consumers of beef cattle and, at the same time, the users of the slaughterhouse. It can be stated that pricing being reference was when beef cattle was in intermediate trader/broker readily distributed to the big trader, being endconsumers/business consumers of beef cattle and users of the slaughterhouse as well as retailers of beef cattle to a traditional and modern market, as occurring in Tomohon City, Manado City and other cities in North Sulawesi. While related to the market structure of beef cattle, it showed a fierce oligopoly and intermediate trader/broker could cooperate with the big trader as end-consumer in determining beef cattle's price. In fact, the big trader bought beef cattle in a great number, so that price per cattle could be pressed down. In case, big traders received profit due to cost-minimizing of purchasing and transportation costs. Big trader/end-consumer of beef cattle, hence, could purchase the greatest number of beef cattle, so such trader obtained the cheapest purchasing price and most efficient since transportation cost could be cheaper. Prices in the sub-distribution level would follow this price, where it considers other additional costs and desired margin. Consequently, the price of beef cattle of the level of end-consumer in the traditional and modern market became relatively high, such as IDR 100,000 - IDR $120,000 / \mathrm{kg}$. The result of this research was in line with other researches $[43,44,45]$, setting out that the bargaining power of breeders was extremely powerless in the marketing chain of beef cattle and dairy due to the significant role of intermediate and big trader in managing marketing distribution so that they obtained a relatively bigger profit than breeders. In the end, this situation caused inefficient market. 


\section{Conclusion}

Based on the result of this research, it can be concluded that the market of beef cattle in North Sulawesi was a fierce oligopoly, showed by a firm concentration of market characteristic on intermediate traders/brokers and big traders as end-consumers or business consumers of beef cattle, the users of the slaughterhouse, and retailers of beef cattle to both traditional and modern market. The intermediate traders/brokers and endconsumers/business consumers of beef cattle were sub-producers being price controllers/determiner in the distribution line of beef cattle marketing in North Sulawesi since they received a relatively higher profit than the producer of beef cattle.

For such circumstance, it, further, is required innovation and strategy in improving the competitiveness of new actors if they are going to enter marketing chains of beef cattle, such as production efficiency and increasing quality of beef and cattle through innovation of feed usage and reproduction technology, agribusiness modernization of beef cattle under partnership program or collaboration with more advanced breeders from other regions. Also, it is necessary to make government regulations related to the price of beef cattle so that traders have price references in the pricing of beef cattle, where it does not give adverse effects on breeders.

\section{References}

1. Biro Pusat Statistik Sulawesi Utara, Sulawesi Utara Dalam Angka, (2020)

2. E. Wantasen, U. Paputungan, Alanya Ac. Rev J, 2(3), 213-224 (2018.)

3. F.H Elly, A. Lomboan, C.L. Kaunang, M. Rundengan, , Z. Poli, S Syarifuddin, Anim. Prod, 21(3), 143- 147.(2019)

4. S.J.K Umboh, J.K.J Kalangi, B.D.Rosari, IOP Conf Series, Earth Env. Sci, 637 (1), 012093 (2021)

5. J. Lainawa, P. Kindangen, T.O Rotinsulu, J.F.A Tumbuan,Int.J.Appl..Bus. Int Manag, 4(1), 1-12 (2019)

6. L.S Kalangi, Y Syaukat, S.U Kuntjoro, A. Priyanti, Livestock. Res. Rur. Dev, 28(12), article \#226 (2016)

7. C.A. Kibona, Z Yuejie, Plos one, 16 (4), 1-14 (2021)

8. A.H.S Salendu, M.L Rundengan, F.H Elly, T.F.D Lumy, Int. J..Env.Agric.Biotech, 5 (5), 1304-1307 (2020)

9. E. Wantasen, U. Paputungan, J Agric. Vet Sci., 10 (7), 06-12 (2017)

10. S.A Loison, C.Bignebat, J. Poverty.Allev. Int. Dev, 8 (1), 1-34, (2017)

11. A. Daroini, J. Man Agribisnis, 13 (1), 55-62 (2013)

12. J. Dzanja, P. Kapondamgaga, H. Tchale, Int. J. Bus. Soc Sci, 4 (6) , 92-102 (2013)

13. M.O.A Bushara, M.K.A Abdelmahmod, Int J. Econ. Manag. Sci, 4(7), 1-5 (2015)

14. A. Ismareni, Muani, Komariyati, J. Soc. Econ. Agric, 7(1), 100-110 (2018)

15. M.J.R.Kadigi, L.I. Kadigi, G.H. Laswai, J.J. Kashaigili, Academia J. Agric. Res,1(7): 20 - 30 (2016)

16. B. Pabbo, J. Galung Tropica, 5(2), 130-142 (2016)

17. R. Anindita, A.A. Sadiyah, N. Khoiriyah, D.R Nendyssa, IOP Conf. Ser. Earth Env. Sci, 411, 012057 (2020)

18. R.C.S. Pratama, K. Supranianondo, Int. J. Env. Agric. Res, 3 (12), 53-56 (2017) 
19. A.I Mongi, E. Wantasen, A.H.S. Salendu M.A.V. Manese, Zootec, 39 (2), 337-344 (2019)

20. A.Fitriani, H.K. Daryanto, R. Nurmalina, S.H. Susilowati, Int. J. Poult. Sci, 13 (4), 191-197 (2014)

21. B Setiaji, I Susila, H.D Wahyudi, Expert. J. Bus. Manag, 5 (2), 129-135 (2017)

22. M. Naderifar, H. Goli, F. Ghaljaie, Strides. Dev. Med. Educ, 14 (3),1-4 (2017)

23. M Agustin, M. Hayati, Agrisocioeconomics, 4(1), 14-21 (2020)

24. S. Ayele, L. Zemedu, B. Gebremdhin, J. Biol. Agric. Health, 7(5), 5-11 (2017)

25. D. Yuzaria, M.I. Rias. J. Adv. Agric. Tech, 4 (4), 324-330 (2017)

26. D.R. Nendissa, R. Anindita, N. Hanani, M.A. Wahib, Russian J Agric Soc.Econ Sci, 6 (78), 379-384 (2018)

27. J.F Barahona, B. Trejos, J.W. Lee, W. Chulaphan, Ch. Jatuporn, Procedia 8, 141-145 (2014)

28. V. F. Pozzo, T.C. Schroider, L. J Bachmeier, Proc. NCCC-134. Conf. App.Commodity Price Analysis, (2013)

29. A. Bayaner, M. Ismihan, O. Bor, New Medit, A Mediteranian J. Econ.Agric. Env. 13 (2), 2-8 (2014)

30. J.A. Ruslan, M. Firdaus, Suharno, Buletin Ilmiah Litbang Perdagangan, 10 (1), 103128, (2016)

31. N.A. Rezitis, M. Tsionas, Econ. Modelling, 76, 216-230 (2019)

32. U.W. Ningsih, B Hartono, E. Nugroho, Jurnal Ilmu Ilmu Peternakan, 27 (1), 1-11 (2017)

33. A Agus., T.S.M. Widi, Ausralasian J. Anim. Sci. 31 (7), 976-983 (2018)

34. N. Gebreselassie, J. Fisheries.. Livest. Prod, 6 (3), 1-3 (2018)

35. S. I. Dlamini, W.C. Huang. Sustainability, 11 (9), 5185 (2019)

36. T..T..Z Win, A. Campbell, R.J.S. Magalhaes, K.N. Oo, J. Henning, Trop. Anim. Health. Prod, 51, 643-654 (2019)

37. D. Yuzaria,,. M.I. Rias, .J Adv.Agric.Technol 4 (4) : 324-330 (2017)

38. Z. Bassa, T. Woldeamanuel, Curr.Inves.Agric.Curr..Res, 4 (3), 542-548 (2018)

39. A.K Sunyigono, Agriekonomika, 8(2), 156-167 (2019)

40. J. Weydekamp, T.D.F. Lumy, E.K.M. Endoh, F.N.S Oroh, Zootec , 39 (2) , 435-443 (2019)

41. P. Motta, I.G. Handel, G. Rydevik, S.M. Hamman, V.N. Ngwa, V.N Tanya, K.L. Morgan, B.M.D Bronsvoort, T. Porphyre, Front. Vet. Sci, 4:244 (2018)

42. D. Smith, S. Waldron, Ph.Sy.Hiew, L. Pham, Asian Cattle and Beef Trade Working Papers, 3, 1-20 (2018)

43. M. Manhanga, L. Musemwa, M Sibanda, S. Ndhleve.. J Hum Ecol 70 (1-3): 67-78 (2020)

44. G. Ordofa, L. Zemedu, B Tegegne. 2021.. Cogent Food \& Agric. 7 (1): 1-20 (2021)

45. T. Angkuraseranee, B. Somboonsuk, S. Sukhabot, S. Nimsai, Int. J. Agric. Technol, 15 (6), 807-822 (2019) 